\title{
Popular and Solidarity Economy: Policies and Realities in the Local Context-The Case of the Agricultural Productive Associations of El Valle, Ecuador
}

\author{
Gliceria Gómez-Ceballos *, Juan Pablo Vázquez-Loaiza, Dora Priscilla Herrera-Torres and Ana Julia Vega-Luna
}

\section{check for}

updates

Citation: Gómez-Ceballos, G.; Vázquez-Loaiza, J.P.; Herrera-Torres, D.P.; Vega-Luna, A.J. Popular and Solidarity Economy: Policies and Realities in the Local Context-The Case of the Agricultural Productive Associations of El Valle, Ecuador. Sustainability 2021, 13, 13469. https://doi.org/10.3390/ su132313469

Academic Editor: Julio Berbel

Received: 15 September 2021

Accepted: 24 November 2021

Published: 6 December 2021

Publisher's Note: MDPI stays neutral with regard to jurisdictional claims in published maps and institutional affiliations.

Copyright: (c) 2021 by the authors. Licensee MDPI, Basel, Switzerland. This article is an open access article distributed under the terms and conditions of the Creative Commons Attribution (CC BY) license (https:/ / creativecommons.org/licenses/by/ $4.0 /)$.
Grupo de Investigación de Gestión de las Mipymes, Universidad Politécnica Salesiana, Cuenca 010105, Ecuador; jvazquez@ups.edu.ec (J.P.V.-L.); dherrerat@ups.edu.ec (D.P.H.-T.); avega@ups.edu.ec (A.J.V.-L.)

* Correspondence: ggomezc@ups.edu.ec

\begin{abstract}
The popular and solidarity economy (EPS) emerges as an alternative approach to poverty aligned with the principles of sustainable development; in this sense, some countries in the region have adopted policies for its growth and development, among them Ecuador. The experience of a rural community was shown; the objective of the study was to identify the factors that hinder the achievement of better efficiency indexes, regarding the implementation of policies at the local level, with respect to rural productive associations. The case of the agricultural productive associations located in the parish of El Valle, Cuenca, Ecuador, was studied. The type of research was mixed: quantitative to support the information extracted from the instruments applied and derive the pertinent analysis and qualitative to collect primary information from the actors involved in the study. We used the action research model through the use of surveys, interviews and focus groups. The key contribution of this work was to making visible and understanding the needs of the rural communities of the sector from their development perspectives, respecting their ancestral knowledge and articulating from the academy the private-public action for the generation of policies for governance, effective application of democracy and promotion of the technical and associative potential of the agroecological productive units. The results show regularities in terms of their socioeconomic situation, their mode of action and the impact caused on their productive dynamics by the atomized decisions of local actors in the exercise of governance. These fail to articulate the implementation of policies at the territorial level to the detriment of their effectiveness and efficiency and, therefore, do not bring about substantial changes in their levels of dependence and dynamics of productive activity-diagnostic components that will be used for the formulation of joint multilevel policies.
\end{abstract}

Keywords: agricultural productive associations; policies; sustainability; popular and solidarity economy

\section{Introduction}

Poverty rates in Latin America have been on the rise, a situation that is accentuated in rural areas, and the policies implemented by the countries that are part of this bloc have not been able to eliminate the causes of this situation. The causes [1] date back to colonial times and are reflected today in the permanence of conditions of structural inequality and unequal exchange. Under these conditions, the countries of the periphery bear the brunt, provoked by a clear dependence for their economic growth on the exploitation of natural resources, sustained by an economic model of primary production, which is based on the exploitation of natural resources.

As an alternative to this situation, some of the countries in this zone (Brazil, Bolivia, Argentina and Ecuador) developed a PES approach. This promotes the presence of a new organizational form whose operating base is based on respect for sustainability principles, generating policies around their performance and inclusion in the prevailing economic systems in these nations. However, as the statistics show, the levels of poverty reduction do not reach the desired results. (The economic theory of development was considered 
as a theoretical approach systematized mainly by the Economic Commission for Latin America and the Caribbean. It was initiated by its secretary Raul Prebisch (1901-1986), who served as secretary of the organization between the years 1950 and 1963, and was founded and documented by the historical-structuralist method in several currents such as the dependency theory, among whose representatives is Ruy Mauro Marini [2].)

Poverty rates in the region are not encouraging, and Ecuador shows a similar situation, occupying fourth place in inequality according to the GINI index as of December 2020, a poverty rate of $32.4 \%$, nationally, $25.1 \%$ in the urban sector and $47.9 \%$ in rural areas, with $27.5 \%$ of extreme poverty [3]. These figures show that economic policies are not enough to solve the country's existing problems.

Under these scenarios, the present research was developed in productive associations of the El Valle Parish, Cuenca, Ecuador, which work around organizational forms of family agriculture. Its objective was to identify the factors that hinder the achievement of better efficiency indexes in the implementation of policies at the local level, with respect to rural productive associations, by presenting the case of productive associations that operate in rural areas and remain in a situation of poverty. Currently, these associations, made up of families involved in agriculture, do not show results of significant progress in the management of productive processes and their commercialization, aiming at consolidating the PSE economic model.

In this way, and according to the background reviewed in relation to the selected research topic, a gap was identified around the scientific discussion on the efficiency achieved by the execution of policies, especially around two perspectives: the efficiency in the execution of public policies and inter-institutional articulation at the national level of the public sector regulatory bodies and the Secretariat of Popular and Solidarity Economy and, on the other hand, the analysis of the contextualized knowledge of the territory and its culture, two aspects that are currently mismatched or are downplayed, causing an irreconcilable unilateral view to prevail.

The study adhered to the participatory research method, in which the subject is an active part of this process [4]. The university was integrated into the problems of the rural territory, and an understanding that this is characterized by an intimate relationship with nature and socio-environmental systems was articulated. Innovation in rural areas should be framed in transdisciplinary research and participatory approaches [5].

Among the main results, the low effectiveness of the policies implemented in the country for these rural contexts is evident, given the insufficient integration among the actors and the absence of a clear direction. Therefore, people whose livelihoods depend mainly on agriculture and are grouped in organizational forms of family farming live in poverty trying to develop alternatives under the associative form. However, the gaps in their management, their levels of dependency and the existing market failures prevent them from achieving the desired results.

In response to this problem, the research questions that were used to evaluate the levels of efficiency and effectiveness achieved in the implementation of policies associated with rural associativity, through the analysis of the selected variables, focused on the following questions: Has the socioeconomic situation of agricultural productive associations changed substantially in the last 10 years? What are the organizational problems present in the associations that impede development and growth despite the existence of policies? Does governance in favor of compliance with national policies favor the development of these forms in the local context? In addition, we wanted to know if the academy can be an articulating and supporting agent in the generation and execution of public policies to promote the development of rural communities.

\section{Theoretical Framework}

The research was based theoretically and methodologically on the PES approach and its link with the exercise of governance at the territorial level, around family farming and poverty. Organizational forms under the PES approach arise as a response to the situation 
of inequality existing between the central countries and those of the periphery-and even the manifest inequality within these countries, which is the main cause of poverty in these contexts. Rural territories are the most vulnerable and have suffered the greatest impact over the years.

The term "poverty", to which the research adhered, is the concept developed by the United Nations Development Program (UNDP). This concept states that human development is a process through which the opportunities of individuals are expanded, the most important of which are a long and healthy life, access to education and the enjoyment of a decent standard of living [6]. It clearly expresses the importance of access not only to a basic basket that ensures survival but also to the enjoyment of services that offer higher levels of gratification, a concept expanded in the 2014 and subsequent reports. There is a growing consensus on the multidimensional nature of this concept; it is recognized that everyone needs to decide freely and be informed about their life choices and have equal opportunities [7].

There is no doubt that the change of this situation and its passage to a higher stage was linked inextricably to the development of human capacities, placing them at the center of this development.

Poverty is deeply expressed in rural contexts. In these spaces, the form of family farming prevails, understood as agricultural, livestock, forestry, fishing and aquaculture production, with limited access to land and capital resources, as well as a preponderant use of family labor force, an economic activity that eventually becomes the main source of income complemented by other activities [8].

According to the studies conducted by [9], in the search for a consensus on the characterization of the term, it was proposed that, in essence, it is agriculture in which the rural and fishing family participates for the extraction of natural products. The essential purpose is self-consumption, which does not prevent them from carrying out exchange activities or the use of simple manual instruments and technologies, as well as developing a strong sense of belonging to the community.

All the theoretical discussion on the subject points to the fact that the relationship between family labor and productive activity stands out [10]. As an economic category, it is strongly tied to the diversity of the context and to the performance of factors such as the geographical situation that defines the distance to markets, economic and historical-cultural processes and the link with the territory [11]. Moreover, because the family grouping is a multidimensional construction with a relative situation of autonomy or dependence with respect to the different markets [12], it is summarized in family farming, associated with peasant agriculture, smallholder agriculture or subsistence agriculture, assuming these are interchangeable terms of equal meaning [13].

It follows that the main elements that make up this type of structure are the ownership of small extensions of land in which direct family labor predominates. The results are essentially destined to subsistence, subject to factors that act unfavorably in their development, such as difficulties in accessing sources of financing, technology and markets.

The study of this problem in Ecuador shows that there is a marked inequality within the sector between large and small producers, on whom the international economic order imposed by the capitalist system implied a deep dependence on primary production. This translates into food insecurity and the degradation of natural resources subjected to intensive exploitation [14]. This is further aggravated by the fact that the national economy does not recognize agriculture as a pivot and the inexistence of productive linkages [15-19].

In the country, peasant agriculture is characterized by an average farm size of 1.8 hectares [17]. There is great inequality in the structure of these family groupings; their characteristics are shown in Table 1. 
Table 1. Characteristics of the organizational forms in the agricultural sector of Ecuador.

\begin{tabular}{|c|c|c|c|}
\hline Organizational Form & Land Ownership & Water Use & Chemical Usage \\
\hline Corporate agriculture & $\begin{array}{l}80 \% \text { of the land is } \\
\text { concentrated in } 15 \% \text { of the } \\
\text { agricultural production } \\
\text { units (UPAs) }\end{array}$ & $\begin{array}{l}\text { It uses } 63 \% \text { of } \\
\text { the water for } \\
\text { irrigation }\end{array}$ & $\begin{array}{l}\text { Indiscriminate use of } \\
\text { agrochemicals and } \\
\text { energy for agroexport }\end{array}$ \\
\hline Family farming & $\begin{array}{c}\text { Represents } 84.5 \% \text { of the } \\
\text { UPAs with a concentration of } \\
20 \% \text { of the land }\end{array}$ & $\begin{array}{l}\text { Uses } 37 \% \text { of } \\
\text { water for } \\
\text { irrigation }\end{array}$ & $\begin{array}{l}\text { Its destination is } \\
\text { essentially to satisfy } \\
\text { the needs of the } \\
\text { family ( } 41 \% \text { of } \\
\text { production) }\end{array}$ \\
\hline
\end{tabular}

Studies on the subject highlight at least three trends that explain this phenomenon: (a) the relative failure of rural development policies (RDPs) aimed at boosting the family economy, (b) the emergence of a process of revaluation of the rural environment in a context of a global food crisis and (c) the consolidation of social movements that propose food sovereignty and sustainability as the axis of policies toward the agricultural sector [8].

From the point of view shown in the rural contexts of the country, the alternative of enterprises with a PES approach seems to be viable. The integration of efforts in a project of this nature can generate synergies that facilitate social development and poverty alleviation.

The existence of this organizational form, as a productive economic activity, has been present in the currents of thought since the 19th century [16]. On this, Reference [18] sustained the idea that the integration between the terms "economy" and "solidarity" comes to mean the mixture between the scientific contribution by the economy and values and the ethics contributed by solidarity. The latter, becoming an alternative to poverty, introduces the analysis based on the combination of traditional and modern competences in the face of utility, scarcity, profit, competitive advantages and efficiency $[18,19]$.

In addition, Reference [20] broadened the term "popular economy" to include human development, linked it to the informal economy, defined that this does not imply disconnection from the capitalist market and emphasized the need to achieve integration between the eco-economic, political and cultural aspects, as well as growth and development. Theories define a line of thought that identifies three currents: the first seeks reinsertion through work acting at the microeconomic level, the second refers to the creation of an organic sector (subsystem) of PES, and the third current thinks and acts at the systemic level and seeks to build another economy [21].

As can be seen, Reference [20] analysis focused on the need to incorporate cooperativism and solidarity into the term "economy", privileging values over capital, which have to be concretized in the integration of traditional resources and capabilities; meanwhile, ref. [22] pointed out that this form coexists with the capitalist mode of production.

On the other hand, Reference [22] summarized the approaches of several authors to the term, indicating that the solidarity economy emerges as an alternative mode of production and distribution to capitalism, created and recreated over the years by those who cannot be exempted from the labor market. It also indicated that, rather than alternatives, they would be differentiated parts but in essence subordinate to the existing mode of production oriented toward use value and not exchange value. In addition, Reference [23] presented a different way of thinking, categorizing it as a utopian perspective of impossible construction and recognizing the need for the conformity of mixed economy scenarios with differentiated logics.

From a theoretical perspective, the existence of this economic form is justified; however, from a practical perspective, the prevalence of values linked to cooperation and solidarity over the accumulation of capital confronts the dilemma of individual versus collective interest. Individual interest has maintained an important weight since the last decades of the 18th century and has formed an indissoluble part of the human personality, supported by a culture of competition. Therefore, the change from a competitive culture 
to a collaborative culture takes time, even when it comes to developing these forms of economic activity in rural areas, where, in some way, ancestral traditions are still present in which mutual aid is practiced as a custom.

The term is used in different meanings-solidarity economy, community economy, popular economy, popular and solidarity economy, social economy, social and solidarity economy and labor economy, among others-which shows that these approaches and points of view have not yet been systematized to form a finished body of concepts and categories. The concept of EPS was used in this research because it is the one legally used in Ecuador.

The emphasis on this type of economy joins the criteria on local development as an alternative [24-26] based on structural changes, taking advantage of endogenous resources. Reference [25] contributed to the discussion aspects such as the basic value of the economy in a regime of Good Living, which is linked to the solidarity proposed as an alternative under construction to the dominant capitalist development paradigm.

In view of this controversy, from the authors' perspective, the PES coexists in the context of the capitalist production model as a different form of business organization. In this sense, it is therefore aligned with the second current put forward by Coraggio, who argued that it is possible to develop a subsystem that integrates harmoniously with the subsystems that make up private property and public property [16]. From a theoretical point of view, their existence is compatible, but in practice, the confrontation between these two approaches leads to their success on a small scale. Small associations are limited in their access to the market, financing, highly specialized employment and technology, and yet, especially in the agricultural sphere, associativity is achieved as a means to confront the barriers faced by these family groups in their efforts to alleviate poverty [15]. In order to achieve this systemic approach at the local level, the formulation and implementation of policies from the government at this level, which promote coordinated action between the decision makers of the territory and actors willing to intervene in favor of improving the quality of life of the people living in these environments, are lacking.

From this point of view, the idea of coexistence of this economic form, whose nature is based on the prevalence of labor over capital, requires at least an approximation to the second theory put forward by Coraggio, i.e., a systemic approach to isolated initiatives. Two elements are essential: The first one is policies in favor of real ruptures of conventional systems around production, marketing and redistribution of wealth, which really support the strengthening of associativity. The other, beyond the "what", as economic and social representation expressed in these policies, is the "how". It is associated with the term "gorbenanza", and its meaning is attached to the decision making that involves the people, promoting the viability of this alternative, whose base is not in the accumulation of capital aligned with the conception of the business but in the accumulation of the satisfaction of the needs of its members. It is difficult to superimpose the collective interest over the individual interest when the success factor has been accompanied by individual competencies and interests.

Thus, from this perspective, governance and governability confront each other in terms of policy formulation and implementation. The evolutionary analysis of the first term shows that, at first, it was understood as the public sector's response to the gap between social demands and their solution. Later, it was understood as the consolidation of democracy, and then, there was an overlapping of terms between governance and governability, until it was summarized in the understanding of the formulation and execution of public policies based on multilevel and network analysis [27].

There is a relationship of dependence between governance and governability; thus, the interaction between actors strengthens the capacity of the socio-political system to consolidate itself and provides it with the foundations for the transformation of citizens' needs into more effective policies with a greater scope and impact. There is a relationship of coordination between the two, for which it is necessary to encourage the participation 
of the actors in the decision-making process that promotes a closer relationship between government and society [28].

Governance is understood as the dynamic balance between demands and the capacity of the political system to resolve them, based on the factors of legitimacy, effectiveness and stability [29], which points to levels of analysis of political culture, institutions and public policies and fields of government action in the economic, political and social spheres. In this sense, the degree of governance is determined by government action in public affairs, there being a marked difference between the capacity to govern and government actions [30]. From the above, it is inferred that effectiveness is measured in concrete results derived from government actions. The weight of governance in democracy is more significant in form and content [31].

Reference [32], after an exhaustive review of the term, concluded that "governance is a category for the specific analysis of the governmental function, in which both the study of the agencies that determine access to power and the agents that make up the government must be considered". He emphasized the importance of including in any analysis of governance the transformation of decisions into actions and vice versa, i.e., the influence of these in the new formulation of policies, thus understanding that governance becomes a two-way process, and its stability is determined by the consolidation of this interaction.

In this process, governance refers to the implementation of public policies with emphasis on sectoral aspects such as health, education and poverty [33]. "It involves government action, but is not reduced to it alone, but also includes the action of economic and social actors" [34]. This analysis highlighted the need to promote the integration of actors with a systemic approach, leading the government to prioritize coordination between the public, private and social sectors over the subordination of the public, private and social sectors [34].

It is, therefore, a new form of government, in which the state is part of a network of actors that adhere to the government in a transversal manner, promoting decentralization and autonomy, so that the state becomes a hierarchical entity that coordinates the process of policy formulation, implementation and control [35].

In recent times, this term has gained greater relevance for the territorial context, particularizing at this level the performance of interests and actors in the formulation and implementation of policies at the local level, even to the point of discussing the expressions "territorial governance" and "local governance", processes that have gained greater popularity in Latin America [36].

The territory is the scenario where branch and territorial policies must be articulated in order to dynamize local development, focusing on how to enhance the endogenous potential of production factors on a sustainable basis. This is only possible when there is coordination among actors and citizen participation is allowed in this process, under the principle that territorial interests must be in correspondence with branch and national interests.

\section{Ecuadorian Context Regarding Policy Definition}

At the national level, since 2008, Ecuador has been formulating policies that favor good living, whose philosophy integrates harmony with nature, ancestral and current knowledge and the reinforcement of values that reach, of course, the agricultural sector, clearly expressed in the Constitution of the Republic. The constitutional basis in this sense, from this moment on, aims to promote the change from an economy based on growth as a capitalist model of development to an economy based on principles of reciprocity, correspondence and complementarity.

Based on this strategic decision, the laws that favor the existence of companies with a PES approach are listed, the main one being the Law of Popular and Solidarity Economy in which labor prevails over capital [37], promoting the existence of what has been called the third sector of the economy. 
To support compliance with the legal framework established by the country, an institutional system is structured, whose governing body dictates the policies related to the sector, as well as the agencies responsible for the regulation, control and promotion of these practices at the national level, based on the conceptualization of these organizational forms. In this way, the solidarity economy is proposed as a viable alternative to the structural crisis of overproduction and consumerism, seen as an economic subsystem under construction that coexists with the public and private economies to form a single social and solidaritybased economic model [38]. It also creates opportunities for employment, livelihoods and income generation where enterprises are understood as social goals, are people-centered and contribute to equity and social justice [36].

On this basis, the essential orientations of economic policies are defined, whose purpose is directly aligned with the control of market abuses, as well as the redistributive policy, both with the purpose of achieving greater social efficiency in the use of public resources, with a marked emphasis on two cross-cutting axes, the recognition of the heterogeneity of the sector and the anchoring of these policies in the territorial context [39].

In this context, several programs and projects have been generated to strengthen the activity of PES associations in Ecuador and, in general, of producers and/or associations located in areas of poverty. Among these are: the Program to Support the Social, Solidarity and Sustainable Economic System of the National Plan for Good Living-Ecuador (PASES II) with support from the European Union; articulation of solidarity economic circuits to strengthen the actors of the EPS (ACES) for the promotion of short marketing channels; in the area of interest for the subject of this article, the Territorial Rural Development Program (PRODER) with support from Belgian funds aimed at poverty alleviation strategies in selected areas; and more recently, the Strengthening of Rural Actors in the Popular and Solidarity Economy (FAREPS) project to strengthen rural actors in the popular and solidarity economy.

Based on the aspects detailed above, it is possible to affirm that the country has a robust institutional legal framework at the highest level, possibly the most consistent in the South American region. This explicitly states the intention to work toward embracing sustainability as a development alternative, strongly promoted since 2008 with the approval of the new constitution, which, unlike that of 1998, clearly reaffirms this purpose. However, practice has lagged behind these intentions; dependence, in most cases, on external funds, the clash of interests in the territorial context and the prevalence of traditional forms of production, marketing and distribution have weakened the strength of the institutional framework and cast doubt on its effectiveness. Therefore, it is necessary to implement forms that expand their level of effectiveness by acting on the cognition and skills of the members of a community and foster the development of the necessary capacities so that they can align themselves with the purposes of a solidarity economy, in correspondence with the cooperative principles and their axiological framework [40].

In summary, although there is a political will in the country that favors associativity as a concrete expression of governance through the formulation of policies, this does not translate into notable results for small farmers. The analysis described below shows that governance, in terms of participation and integration of actors in the implementation of these policies at the rural territorial level, has been limited in scope. This situation means that the levels of effectiveness and efficiency of these policies have not achieved their objective because the members of these organizations are still in a situation of inequality in the availability of resources and alternatives to strengthen their development and inequity in relation to the distribution of resources and alternatives to strengthen their development.

\section{Materials and Methods}

There are a total of 12,087 associations in the country, $49.7 \%$ of which are productive associations [41]. A total of 8 agricultural production associations in the El Valle area were selected for the study, of which 5 are subscribed to the requirements of the National Secretariat of Planning and Development (SENPLADES) and the rest are productive associations 
subscribed to the Ministry of Agriculture and Livestock (MAG), the first link to move to the entrepreneurial form under the conditions of the National Secretariat of Planning and Development (SENPLADES).

The study was conducted in the parish of El Valle $\left(2^{\circ} 56^{\prime} 16^{\prime \prime} \mathrm{S} 78^{\circ} 58^{\prime} 00^{\prime \prime} \mathrm{O}\right)$ shown in Figure 1, located in the southeast of the city of Cuenca, with an area of 4305.01 hectares and a population of 24,314 inhabitants-11,489 men and 12,825 women-with a poverty level of $63.4 \%$ (INEC, 2010). Productively, the parish mainly grows corn, beans, alfalfa, potatoes, peas and vegetables, complemented by activities such as raising chickens, guinea pigs, pigs and dairy cattle [42].

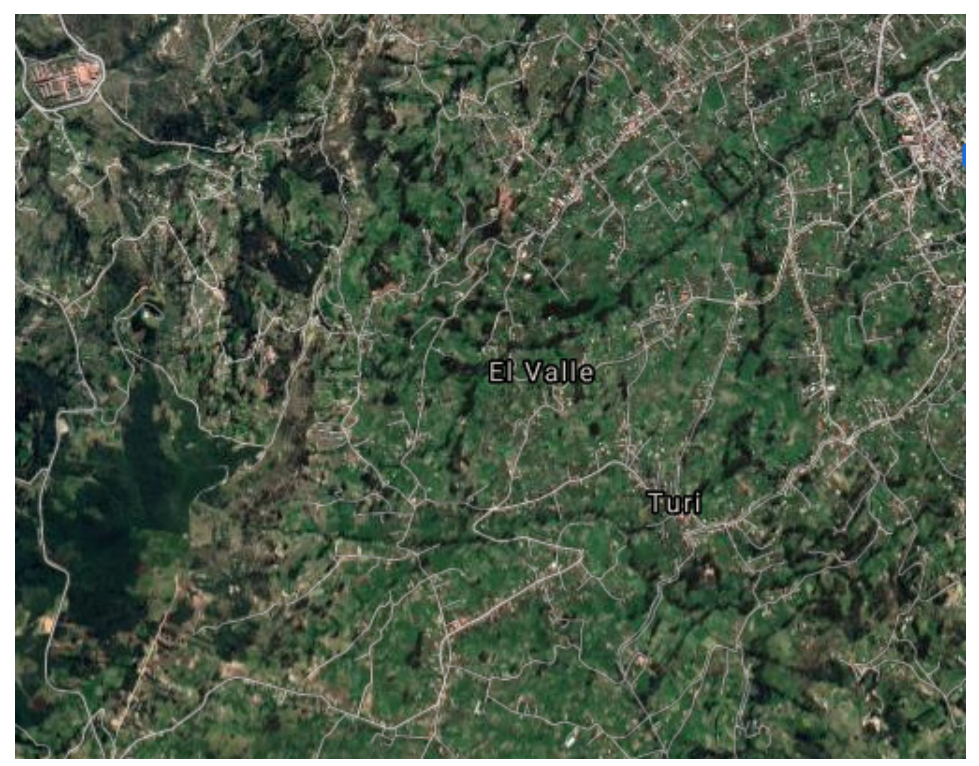

Figure 1. Map of rural parishes of Cuenca, Ecuador. Adapted from Plan de Desarrollo y Ordenamiento Territorial parroquia El Valle.

The type of research applied was mixed, mostly qualitative [43]. It works with quantitative information to show information on productive associations through indicators and statistical analyses that show the current socioeconomic reality of the performance of these organizations and their members, but it is essentially based on human nature from the perspective of man/woman in interaction with the environment.

The methodology used was action research. This methodology involves the search for solutions to specific community problems, focusing on processes that guide decision making for the formulation of projects and reformulation of structural processes, with the participation of those involved, and quantitative and qualitative data are collected, integrating inductive and deductive approaches [43].

Given the choice of this methodology, it was understood that the emphasis of the study was on the qualitative approach, and thus the techniques detailed below were used for the following purpose:

Focus groups with the participation of the members of each organization and with selected actors involved in decision making in the territory to discover from their experiences the answer to the research questions linked to the organizational problems present in the associations that impede development and growth despite the existence of policies and whether governance in favor of compliance with national policies favors the development of these forms in the local context.

The results presented served as the basis for structuring the survey which, in addition to delving into the aforementioned aspects through questions that allowed the quantitative approach to be applied and data processing using SPSS software, served to show evidence as to whether the socioeconomic situation of agricultural productive associations has changed substantially in the last 10 years through a descriptive scope and statistical 
analysis of clusters to determine homogeneous groups and their characterization in the face of the reality of poverty.

The research also recognized [31] sense in a constructive and communitarian perspective of empowerment oriented to the use of power for human development, which is based on three assumptions: power is expandable; shared power and the assurance of the subject's psychological and social super-life and permanence; and where endogenous contributions contribute to the deployment of personal empowerment. It is based on the technical-scientific, derivational and emancipatory perspectives developed by [44].

The use of this methodology allowed the researchers to assume the role of agents of change, together with the people who participated in the research. The use of the various techniques selected led to the reflection of the main problems that demonstrate the ineffectiveness of the execution of policies in this context, as a way to identify and plan their solution, starting with the modification of behaviors, the search for more efficient alternatives for the management of these organizational forms and the generation of projects based on their strengths and weaknesses, in order to direct in a more efficient way the resources they have in the locality and to transform their reality in the order of the administration of the organizations and their repercussions in the economic and social scope.

The techniques used were:

- Interview with a member of the board of directors of the Decentralized Autonomous Government of the parish and in the technical area of MAG that attends the productive projects.

- Observation at a local fair. Every Saturday a fair is organized in the parish, where members of the associations have the opportunity to sell their products. The guide used to apply this technique consisted of evaluating: presentation and variety of the products exhibited; sales prices; and behavior of the vendors. From the exchange with them, information was gathered on the effectiveness of this form of commercialization for the associations, their levels of organization and the extent to which it contributes to the purposes of the association.

- Survey of 91 members of the 8 associations (74.5\%) out of a total of 122; the census was used, and the questionnaire included 13 structured, semi-structured and open questions; a Cronbach's alpha test was carried out with the SPSS program, providing a result of 0.7994 .

- Before applying the survey questionnaire, exchange and discussion sessions were held with the members of each of the associations through focus groups. Discussion was encouraged by formulating the following questions: What are the main problems observed in the organization and how could we solve them? To what extent do the actors who make decisions in the territory, with emphasis on the parish GAD, contribute to the improvement and growth of their organizations? Emphasizing the selected methodology, the participation of all members was encouraged, creating spaces for discussion that promoted the opportunity to clarify their opinion or that of their peers in an informal environment that encouraged dialogue, respecting their language and forms of expression.

- The objective of the survey was to deepen the aspects that the members of the associations had previously expressed as problems, in the spaces mentioned above, and to collect socioeconomic information, variables that allowed the approach to the measurement of the effectiveness and efficiency of the application of policies in this context.

- The technique was applied in a personalized way with each of the members of the organizations so that the meaning of the formulation of each question could be understood, adding in each case the comments to their answers.

- Focus group with selected stakeholders from the parish (8 participants): a member of the Decentralized Administration Government (GAD) in charge of the projects; a MAG technician; a specialist from the Financial Cooperative; and five project researchers. 
The criterion followed was to integrate the points of view of government management, productive activity, the financial cooperative and the researchers.

- During the course of the research, it was considered necessary to add the use of this technique to triangulate the information referred to the prioritization of problems and to identify gaps between what was stated by the community members and the decision makers with respect to the programs and projects that support the execution of policies.

- The variables studied to measure the effectiveness of the policies applied to these contexts were: socioeconomic situation of the members of the association, productions resulting from their economic-productive activity, forms of commercialization and factors related to the perception and attitudes of the members of the organizations toward associativity. The information was processed with SPSS.

\section{Results}

The results section begins with a socioeconomic description of the members of the associations. Secondly, the main problems associated with the management of these organizational forms linked to the production and commercialization processes are presented. Finally, the perception of these people with respect to the decisions taken by the territorial GAD and other actors, who intervene in the territorial space in favor of the fulfillment of state policies, is detailed. These elements serve as a basis for answering the questions formulated in the research.

Next, the results are discussed with respect to research question number 1 understood as: Does the current socioeconomic situation of the members of the productive associations evidence inefficiency in the execution of policies at the local level?

Figure 2 shows the reality of the composition of the family nucleus and its perception of change in the last 10 years and Figure 3 the educational level and occupation.

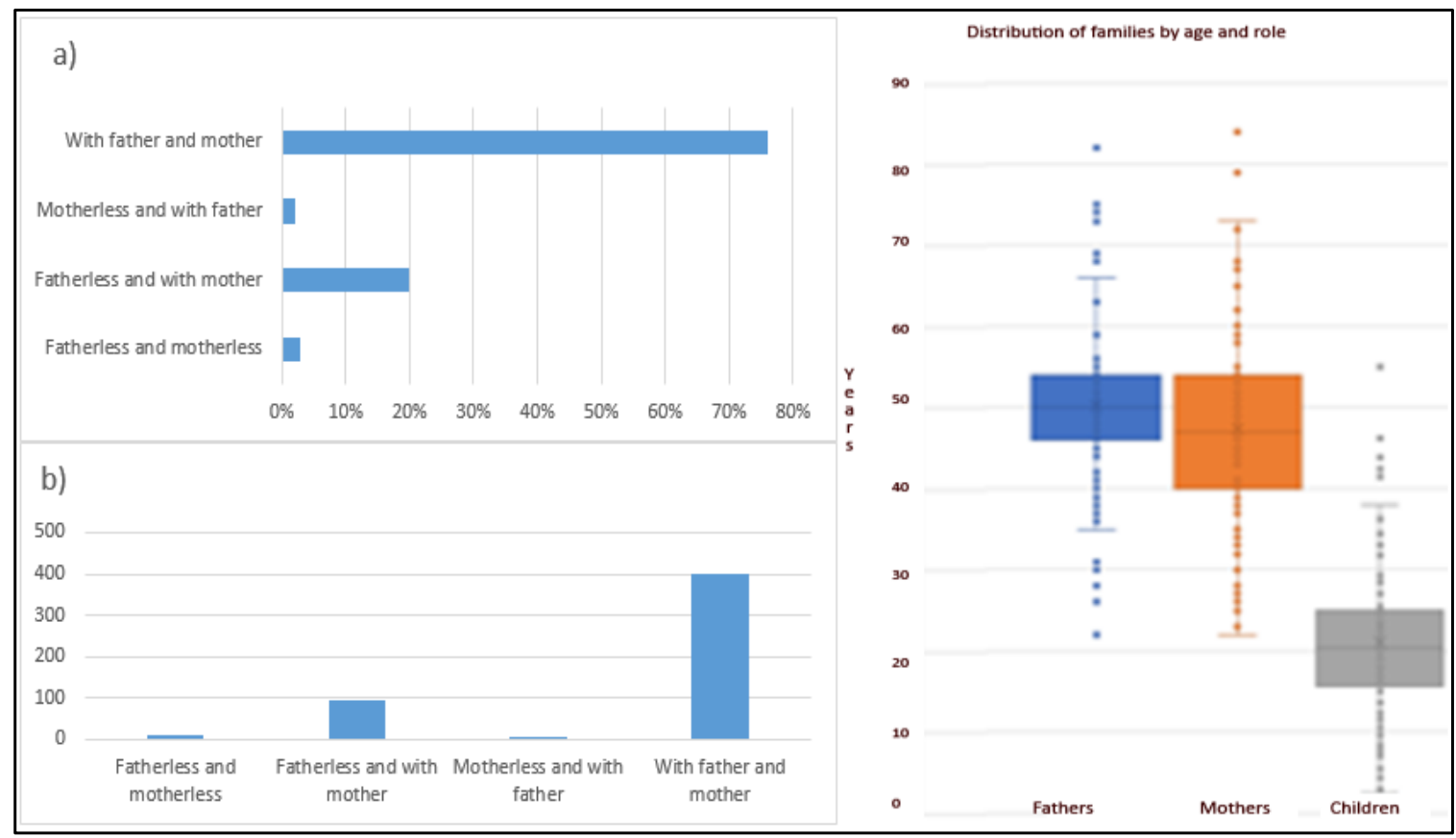

Figure 2. Composition of the family nucleus. Authors' own elaboration based on primary data collection. (a) \% families with father and mother, (b) number of family members. 


\begin{tabular}{|c|c|c|c|c|}
\hline \multicolumn{5}{|c|}{ Level of Education } \\
\hline & Fahter & Mother & Subtotal & Children \\
\hline Household chores & 1 & 58 & 59 & 17 \\
\hline Agriculture & 16 & 21 & 37 & 6 \\
\hline Construction & 25 & & 25 & 22 \\
\hline Miscellaneous trades & 8 & 2 & 10 & 19 \\
\hline Employee & 4 & 3 & 7 & 19 \\
\hline Driver & 5 & & 5 & 3 \\
\hline Retired & 4 & & 4 & \\
\hline Professional & 2 & 2 & 4 & 15 \\
\hline Mechanics & 3 & & 3 & 11 \\
\hline Ohter & 2 & 1 & 3 & 11 \\
\hline Student & & & 0 & 143 \\
\hline Merchant & & & 0 & 6 \\
\hline Not indicated & 21 & 4 & 25 & 274 \\
\hline Total & 91 & 91 & 182 & 546 \\
\hline
\end{tabular}

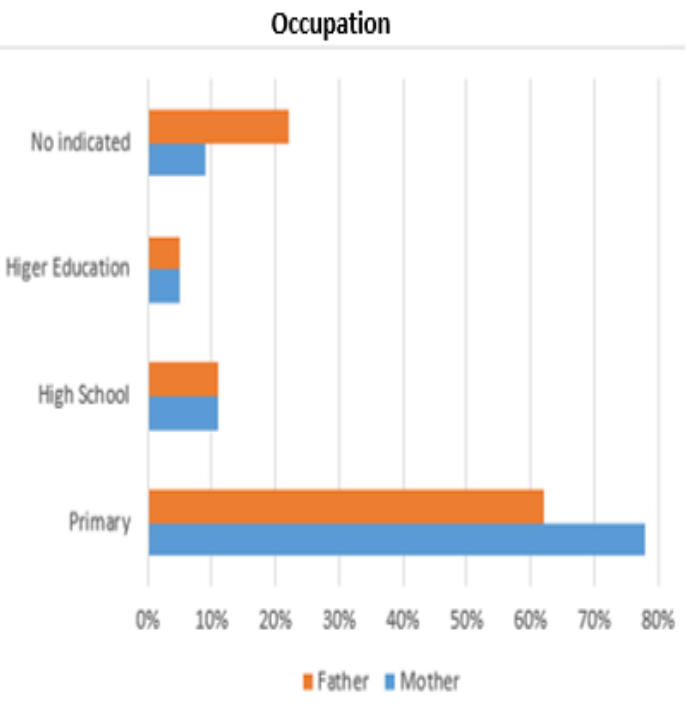

Figure 3. Educational level and occupation. Authors' own elaboration based on primary data collection.

Fathers show a higher rate of occupations linked to the agricultural and construction sectors, while mothers tend to be housewives and the ones who, in general, perform the activities linked to agriculture; this results in that the majority of these associations are represented by women. The ages of the associates (81.5\%) range between 31 and 65 years; only $2.2 \%$ of the children (cannot be children) are engaged in agriculture; the migration of men is significant, finding that $25.3 \%$ of its members reside abroad.

On the other hand, the distribution of families (Figure 4) shows the role of the associate within the family nucleus and their place of residence, showing that the heads of household are the members of the association, suggesting that they are the ones who seek daily sustenance and generate income for the household. In addition, as illustrated in Figure 5, the level of economic income and its destination of expenditure also predict situations of poverty.

In addition, Figure 6 shows the perception of poverty, the economic situation and the current situation compared retrospectively.

\begin{tabular}{|c|c|c|c|c|c|c|}
\hline & & Father & Mother & Children & Not Indicated & Total \\
\hline \multirow{5}{*}{$\begin{array}{c}\text { Head of } \\
\text { household }\end{array}$} & Father & 10 & 42 & 1 & & 54 \\
\hline & Mother & 1 & 29 & 2 & 1 & 33 \\
\hline & Children & & & 2 & & 2 \\
\hline & Not indicated & & 2 & & & 2 \\
\hline & Total & 11 & 74 & 5 & 1 & 91 \\
\hline \multicolumn{5}{|l|}{ Category } & Total & $\%$ \\
\hline \multicolumn{5}{|c|}{ Head of household and member of the association } & 41 & $45 \%$ \\
\hline \multicolumn{5}{|c|}{ Rest } & 50 & $55 \%$ \\
\hline \multicolumn{5}{|l|}{ Total } & 91 & $100 \%$ \\
\hline
\end{tabular}

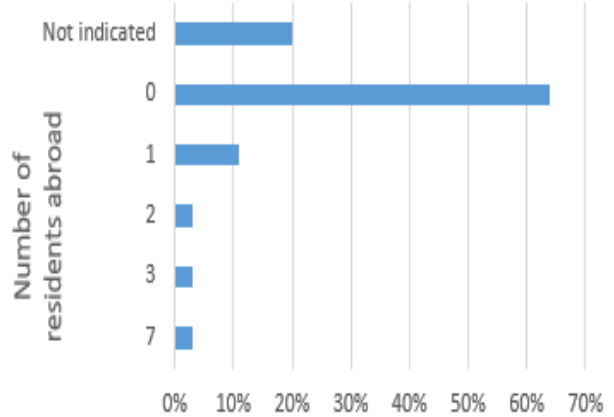

Figure 4. Distribution of families according to the number of associates residing abroad and relationship between the role of the family member and the member of the association. Authors' own elaboration based on primary data collection. 


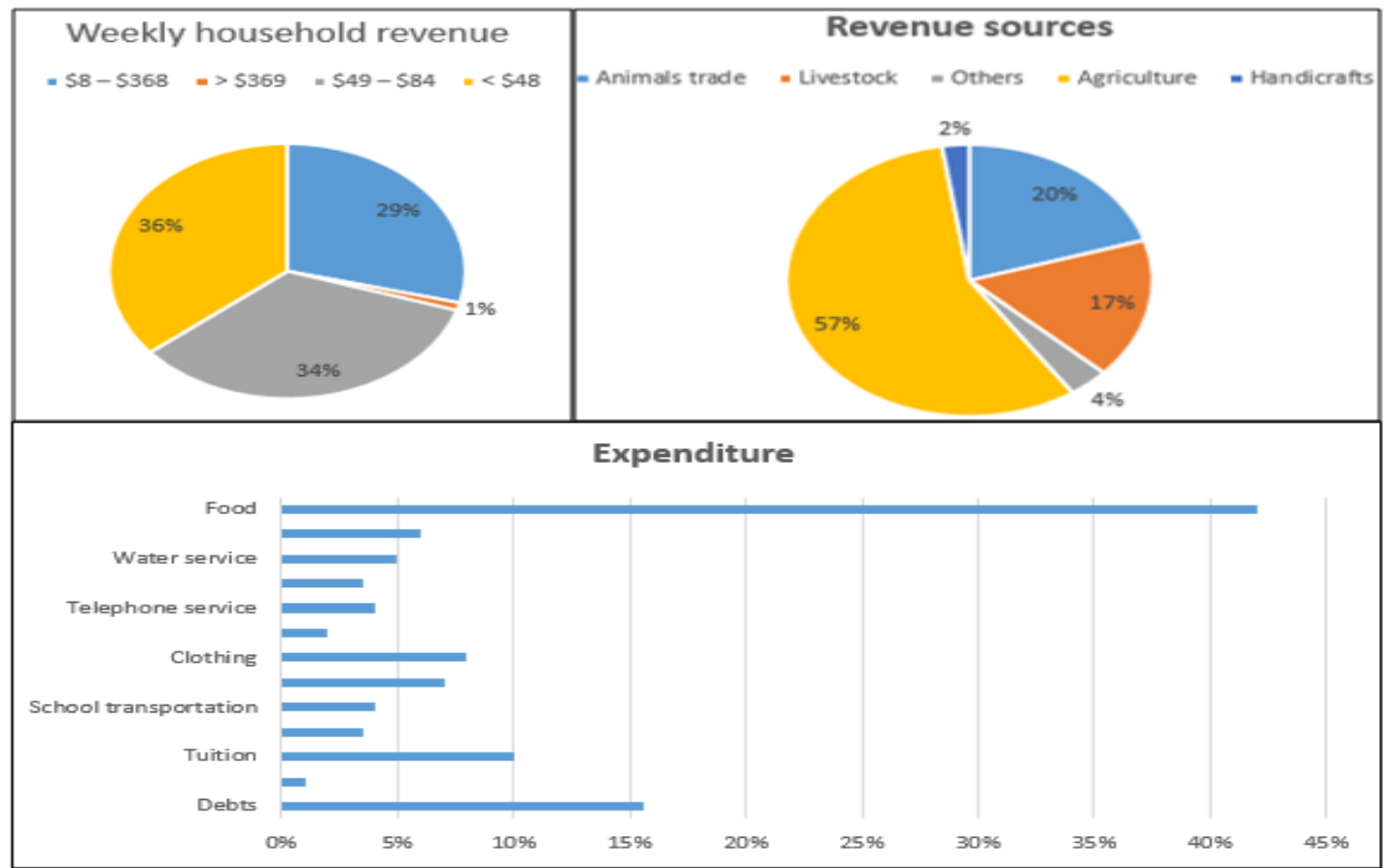

Figure 5. Revenues received, sources of income, expense structure. Note: Authors' own elaboration based on primary data collection. It can be observed that the highest percentage is occupied by those who earn less than USD 48 and between USD 49 and USD 84 per week, and more than half of them state (57.4) that their sources of income come from agriculture; however, the highest level of expenditure is associated with food. The most frequently indicated source of income is agricultural products (53\%). The most frequently indicated income-generating items are vegetables and tubers (51\%), poultry and guinea pigs (15\%) and milk and cheese ( $8 \%)$.

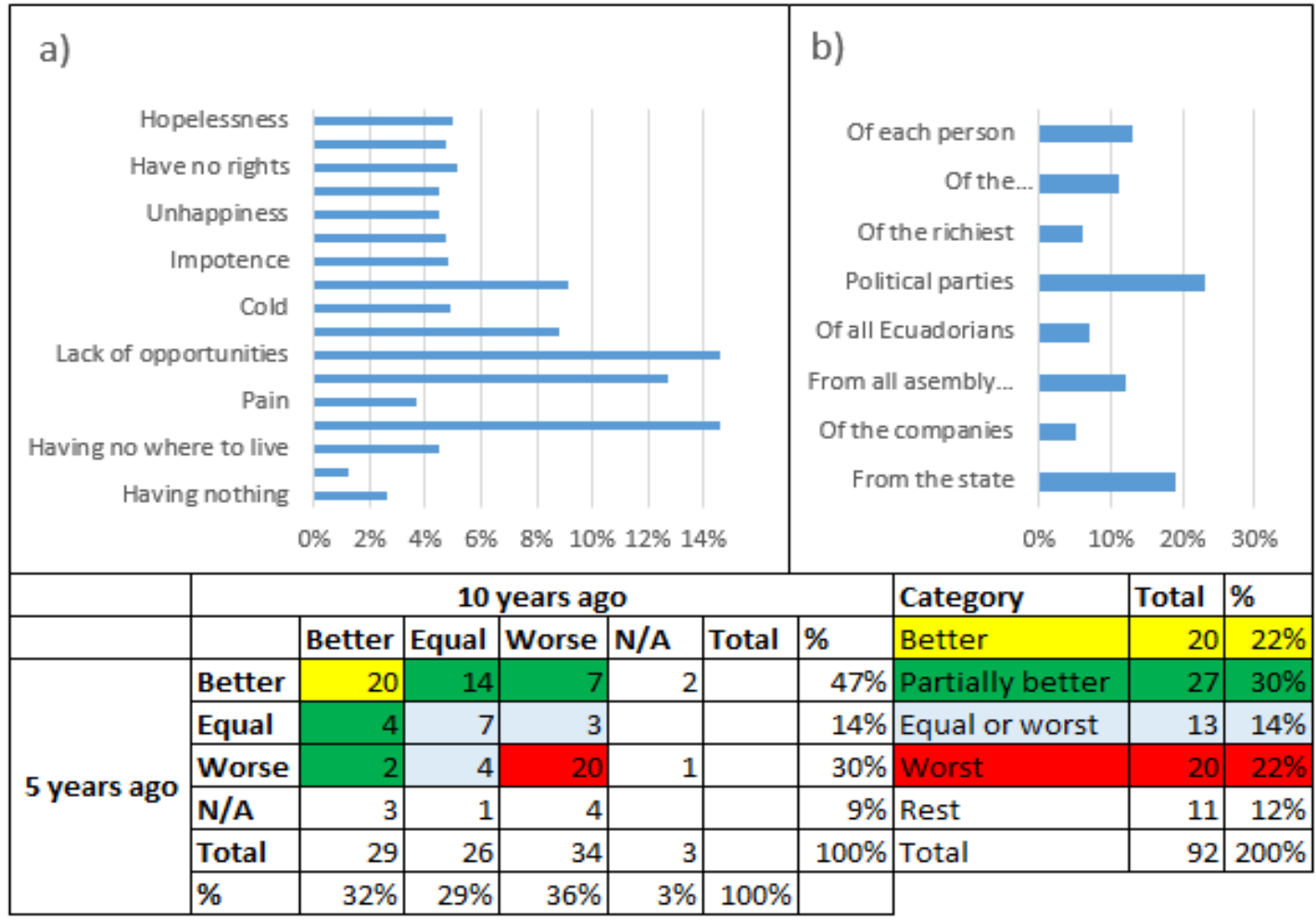

Figure 6. Perception of poverty and retrospective comparison; those responsible for the economic situation. Authors' own elaboration based on primary data collection. (a) Associated poverty perception; (b) stakeholders' perception. 
The perception of poverty is mostly aligned with the lack of opportunities, not having a job and economic problems. Political parties and the state are mainly responsible for the current economic situation.

When comparing income, expenses and average monthly family balance by association, economic differences were observed "Between" and "Intra" associations. The low level of income corresponds to the classification they make according to their perception: $55.5 \%$ consider themselves a poor family, $40.0 \%$ middle class, and $4.4 \%$ consider themselves very poor; that is, from the subjective perspective of poverty measurement, more than half of the respondents define themselves as poor.

From here, however, the results are based on the second research question: What organizational problems do these associations have that impede their growth and development despite the existence of policies?

Regarding the problems that the associations present at the organizational level and that impede their growth and development, the analysis allows us to see the reality of production and forms of commercialization.

Regarding these processes, the results of the interviews and the survey are shown. The essential conclusions derived from the analysis are: (a) the production obtained is essentially destined for consumption, (b) the surplus is taken to fairs and even bartered, and (c) the contact for these markets is managed by the MAG, the GAD and some NGOs. There are two opportunities to take products to fairs, the parish fair every Saturday and in the city of Cuenca. A representative of each association per week can attend the first, which causes inconveniences such as a lack of organization to manage the marketing of products generated in the association as a whole and conflicts among its members.

Each Saturday two members of the organization are selected to take the products to the fair; according to the criteria of the participants, there is no agreement to decide in a coordinated way which products will be taken and in what quantities. Those who are selected decide individually what to bring of their own harvest, which means that sometimes they do not manage to sell all the products. There are no intermediaries, and they use their own means, but since there is no collaboration in the decision, they incur individual costs that could be reduced if there was an agreement.

In correspondence to the quantities produced, the order is as follows: lettuce, broccoli, milk, guinea pig breeding, beans, beets, corn, potatoes, cabbage, tomatoes, onions, pig breeding, cauliflower, eggs and carrots. Between a third and a quarter of the producers production is destined for consumption $(67.2 \%)$. What is destined for sale $(48.5 \%)$ is taken to market $(32.7 \%)$ at fairs, $14.9 \%$ to orders and $4.0 \%$ to other marketing points.

In addition, although they all have the Single Taxpayers Registry (RUC), they do not keep accounting records that systematize the operations of these processes, and they do not prepare production plans; they decide empirically what they are going to produce, depending on the season, the availability of seeds and their own desires.

In the observation of the local fair, it was evident that the products offered by the members essentially cover the needs of the inhabitants of the parish; all the organization of the sale falls on the women. The offer is repetitive; only in one case, the sale of jams that add value to these products was observed. Most of them think that they do not reach a common agreement, either among the members of an association or among the associations, to decide on greater diversification, quantities in favor of the demand or rationalization of expenses for the transportation of the products. This is a reality that in some way is shown in the relationship between expenses and income in Figure 7 . In this regard, $70 \%$ of those surveyed indicate that they have an income of up to USD 84 per month and an expense of more than USD 489. This speaks of an unsustainable situation since their economy is practically covering debt expenses. In addition, when looking for a relationship between income and expenses, a $p$-value of 0.394 was discovered through the chi-squared correlation statistic, which, being greater than the significance level of 0.05 , shows that their expenses are not related to their level of income. 


\begin{tabular}{|r|l|r|r|r|}
\hline ID & ASSOCIATION & REVENUES & EXPENSES & BALANCE \\
\hline 1 & San Pedro & 266 & 278 & -58 \\
\hline 2 & Virgen del Carmen & 266 & 140 & 168 \\
\hline 3 & Santa Marta & 181 & 640 & -425 \\
\hline 4 & El Despacho & 906 & 500 & -256 \\
\hline 5 & Señor de los Milagros & 266 & 372 & -188 \\
\hline 6 & Los Geranios & 906 & 359 & 341 \\
\hline 7 & Virgen del Rosario & 266 & 359 & -74 \\
\hline 8 & San Antonio de Gapal & 96 & 444 & -217 \\
\hline & Average & 266 & 386 & -149 \\
\hline
\end{tabular}
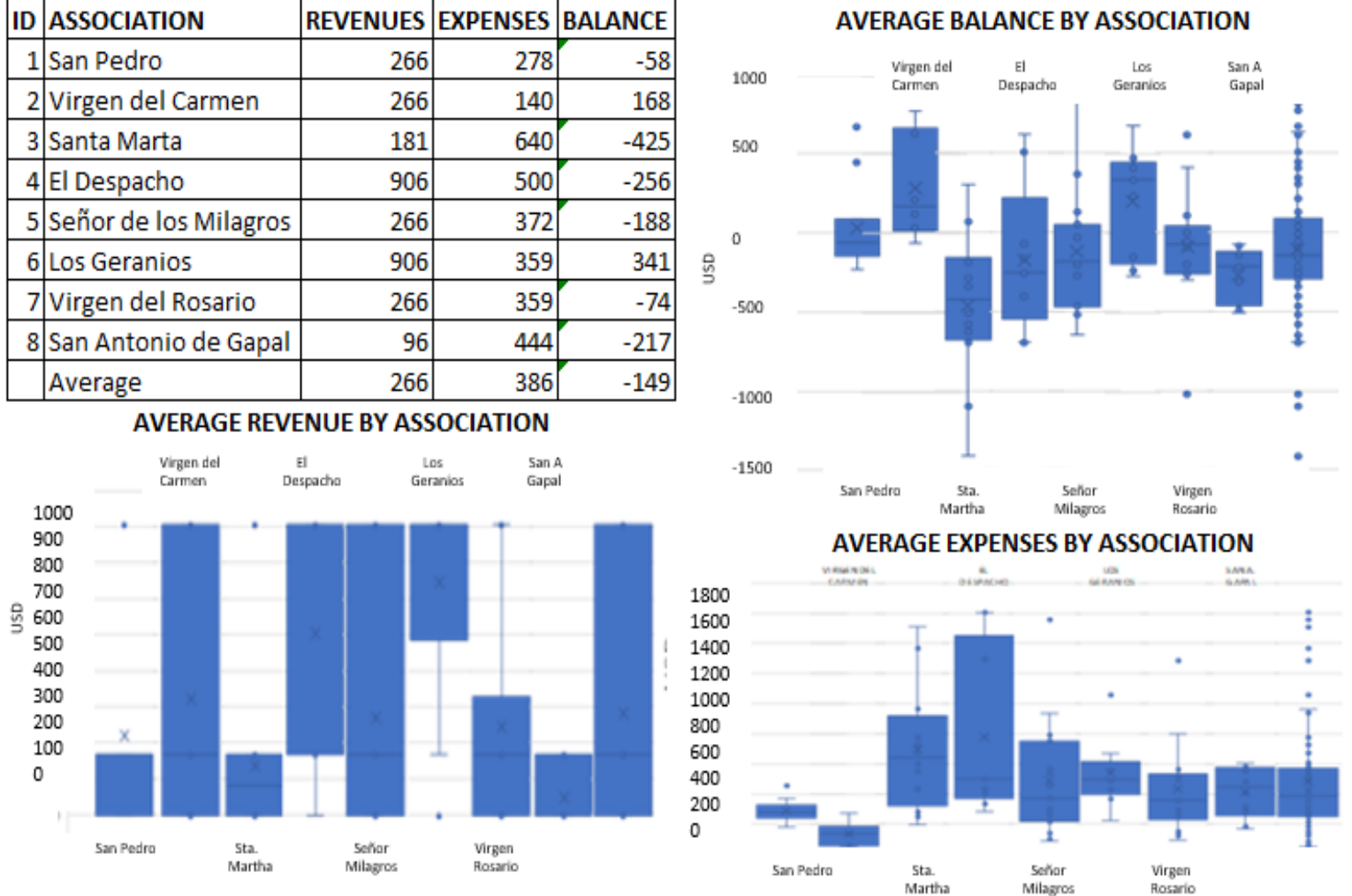

Figure 7. Relation of income and expenses by association.

The following are the results related to research question 3: Does the exercise of governance, in favor of the fulfillment of national policies in rural areas, favor the development of these organizational forms in the local context?

Once the information had been processed and the root causes of the problem had been identified and expanded, it was decided to conduct a focus group to prioritize them from the perspective of the actors who have the greatest influence on these associations.

Eleven problems were listed, and a weighted vote was applied; each participant was assigned 13 votes to distribute among them, under the criterion of giving the most votes to the problem that has the greatest impact on the associations' performance. The results are shown below, ranking the problems in descending order of importance.

1. Low levels of collaboration and teamwork;

2. Insufficient marketing channels;

3. Failure to take advantage of the differentiating factor of organic agriculture in product design;

4. Lack of accounting records;

5. Low production levels;

6. Social conflicts;

7. No production planning;

8. Lack of motivation on the part of the members of the associations;

9. Insufficient awareness of consumers from the perspective of responsible consumption;

10. Insufficient alliance between the associations to collaborate in productive and management activities;

11. Low number of clients.

The three main problems are: the low level of collaboration and teamwork; marketing channels; and the use of the differentiating factor of organic agriculture in product management.

In addition to this, and in relation to the benefit that current policies have on the development of these organizational forms in the local context, the interviews allowed observing factors linked to attitudes toward associativity, unmet needs and support received. 
In this regard, according to the families' reports, the main needs to improve production are water systems (16\%), training (14\%) and technical support (13\%). Access to water sources and irrigation systems is the main difficulty that these associations have in terms of infrastructure due to the natural conditions of the territory.

However, the GAD decides on the approval of projects based on the magnitude and priority of the requested demand. The approved projects refer mainly to requests for infrastructure improvements and productive inputs. There is no participatory diagnosis to identify and prioritize the significance of the problems, aiming at the long-term development of the organization and therefore of the community. In all cases, the values go to lost funds; there is no coordination between the institutions that offer projects, and therefore, the launch of calls for proposals to meet their demands has not been integrated or systematized.

As a consequence, the contributions received are not aligned with their needs, as $78 \%$ of the families indicated having received help in the form of projects (mainly inputs and training), $86 \%$ stated that the effectiveness of these "aids" to improve their economic situation was "Medium" to "Little", 65\% of the families indicated that they had not received help from any state institution in the last year, and $52.8 \%$ of those that had received help indicated that they had received little help to improve their economic situation; these data coincide with the results of the interviews, and only $2.8 \%$ indicated that they had received a lot of help.

On the other hand, the perception and attitudes toward associativity are summarized as follows according to the experience perceived and agreed upon in the focus groups with each of the eight communities that were part of the study and that were carried out in situ to generate a space of trust and security in favor of communication.

Teamwork and the attitude toward cooperation, expressed in terms of companionship, are weak. In view of this, there is a fear among the associates to legalize their enterprise, especially because of the monitoring by the control institutions and the lack of knowledge of the tools necessary for the management of the organizations. Not all associates actively participate in the implementation of the activities proposed by the associations. Among the reasons that justify this attitude are: (a) carelessness or lack of commitment; (b) other jobs; (c) low production; (d) market access is limited for the commercialization of products since it is practically managed by public entities; (e) lack of knowledge of their obligations in tax, accounting and legal aspects and financial indicators; and (f) although they know some agroecological management practices, these are not implemented due to carelessness and lack of follow-up or motivation.

With respect to the expectations and problems of the associations, the application of unsupervised classification techniques (clustering) suggests that the population can be subdivided into four groups as shown in Figure 8.

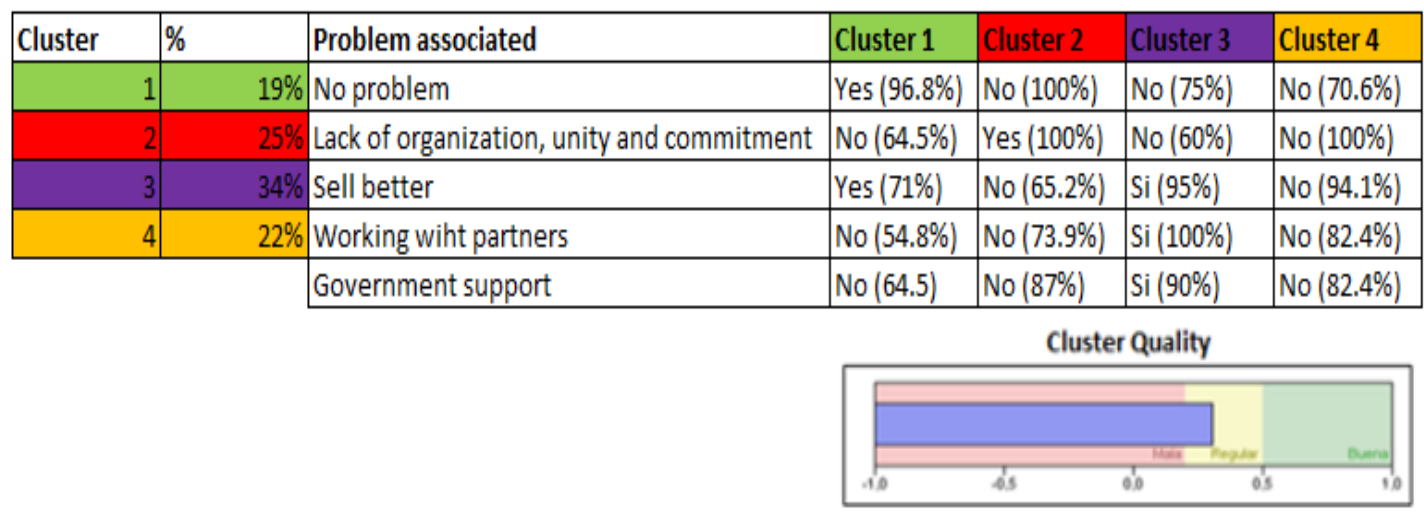

Figure 8. Cluster analysis. Authors' own elaboration based on primary data collection. Cluster analysis through a two-stage algorithm with 17 entries. 
The first cluster covers $19 \%$ of the population and is characterized by families who state that they do not have any problems as members and see the association as an opportunity to sell better. The second cluster covers $25 \%$ of the population and is characterized by families who consider the "Lack of organization, union and commitment" as a problem that affects them individually and collectively. The third cluster covers $34 \%$ of the population and is characterized by families who see the association as an opportunity to sell better, work with partners and obtain government aid. The fourth cluster comprises $22 \%$ of the population and is characterized by families who consider that associations do not have problems.

With respect to the perception of responsibilities and expectations about the economic situation, this technique suggests that the population can be subdivided into two groups: The first group covers $17 \%$ of the population. It is characterized by families that do not expect to obtain either social security, citizen participation or training and, in turn, do not consider that those responsible are either government agencies, the population, the companies, or the richest. The second group covers $71 \%$ of the population and is characterized by families that expect to obtain social security, citizen participation and training and in turn consider national and local government agencies to be responsible. This opens a discussion gap as to whether it is really public policies that cause poverty or the management capacities of organizations.

\section{Discussion}

The reflection induced through the interaction between researchers and members of the associations shows that the policies, programs and projects aimed at promoting the development dynamics of small associated producers do not reach the desired levels in terms of effectiveness and efficiency in the economic and social dimension.

Therefore, the expectations of poverty in the rural locality selected as a case study are not exceeded, and this fact supports the hypothesis that government policy is to subsidize projects that do not arise from the initiative and needs of the population but rather are gifts granted to comply with budgetary allocations. The level of income of the population under study does not cover their basic needs, with the category "Payment of Debts" being second in the expenditure structure. There are marked inadequacies in the management of these associations, which translates into low levels of sales and income, and there is no coordination among the actors who make decisions at the territorial level, generating a low-level impact. This situation, although reflecting the reality of a particular context, is not alien to the rest of the territories of similar nature in Ecuador.

Thus, the socioeconomic characterization of the members of the associations coincides with what was described in the introduction. In general, they are people of scarce resources and low levels of education. More than half describe themselves as poor. There is a significant presence of women as heads of household, whose rate exceeds the national average of $23.9 \%$, and with occupations in agricultural activities, although most are housewives. Men combine farming with other activities, specifically construction, and the income they earn shows that agriculture is not an objectively attractive activity under these conditions.

In addition to the above, there is emigration, an issue that is in line with the situation of the country described in [11], since the lack of economic opportunities in rural areas favors this phenomenon in thousands of people, especially young people, contributing to the feminization and aging of agriculture. The percentage of young people integrated into the agricultural activity is low and, for some reasons, may even be linked to the few existing opportunities for them to assume leadership, which limits the possibilities of change in the territories related to technology and demand [45].

The situation analyzed above is similar to what has been present in the region for years as stated by [46]; agriculture is a complement, and those who work under the family farming modality obtain income from their crops, adding the sale of their labor force. Almost half of the income received by rural families in the region comes from non-agricultural activities. 
Evidence was analyzed showing the real possibility of small agricultural productive associations being successful in their economic activity, developing alternatives to escape poverty and thus justifying that investment efforts be directed to the sector [47]. However, even when small producers have the possibility of being successful, some seek better incomes by carrying out other activities, and thus it is necessary to make these businesses profitable, to prepare them, since only in this way will they be able to develop capacities to face the challenges related to the current limitations [48]. This is not possible without the intervention of policies that act in favor of changing this reality, take into account their heterogeneity and promote associativity [49].

The discussion on poverty favored lack of opportunities, economic problems and lack of employment. These three elements can be somewhat mitigated by encouraging the creation of PES-oriented associative forms. Strengthening them from an organizational perspective, which encourages the real participation of their members in the exercise of governance, could contribute to the empowerment of their members to self-manage their own development. This is supported by the principle of the prevalence of labor over capital and, therefore, the accumulation of satisfaction of needs in an environmentally coherent setting, contributing to the effectiveness of policies. This is all the more important if one considers that associativity is a mechanism for improving the efficiency of these policies by reducing the transaction costs faced by smaller producers individually. However, associative processes themselves involve transaction costs and are unsustainable if their benefits do not exceed their costs [50]. In this case, the benefits that could be generated by these economic forms are limited.

The information survey revealed low levels of organization and management on the farms, including insufficient cooperation among members and failure to take advantage of their potential to generate social capital through interaction processes that influence their development including between communities in the same sector. In addition, they do not include a soil study to look for production alternatives, have the means of production to work the land or have the capital to innovate certain processes, aspects in which the university can make a very successful contribution.

It was recognized that, among the weaknesses present in the management process, is the lack of production planning, which causes a deficit or excess of products at certain times of the year. This situation is the result of planting being carried out empirically, taking advantage of natural bounties, which results in repetitive offers that do not meet market expectations.

The marketing channels are essentially linked to the markets and fairs that have been instituted as part of the policies promoted by the country to support these associations. Although this is a step that has boosted the sector's sales, it is still within a conventional market proposal, which is not very efficient. There is concurrence of many farmers with similar products, causing a perfect competition that leaves little margin of possibilities.

This situation is present in other countries in the region, a situation that was highlighted in the work by [51] in relation to the potential of short circuits and product differentiation through the management of agroecology as an alternative for family farmers to be properly inserted into the market. However, for this, it is necessary for these producers to manage the necessary techniques and have access to information and the market.

An important point of discussion was related to the existing distrust in relation to associativity, which weakens the confrontation with the competition of an undifferentiated market. This means that agroecological products do not find a way to position themselves, as there are no market segments aligned with responsible consumption or policies that cause real ruptures in traditional trade, only small actions that feed the discourse rather than a real change in current practice.

The form of marketing on demand is discarded. This way of marketing products can be organized as it benefits the management of direct channels based on the differentiation factor provided by agroecological production. Direct channels stimulate responsible consumption and take advantage of interaction without intermediation. They contribute 
directly to cost reduction, emphasizing that if the benefits do not exceed the costs, associativity is unsustainable. This leads to the need to promote policies that stimulate the increase of production and yields, applying new methods to reverse this situation-this situation is shown by the study of causal diagrams in coffee cultivation, with an agro-systemic approach, presented by [52] - as well as expanding and diversifying market segments, identifying those for whom the offer is attractive due to the benefits it offers in terms of healthy nutrition and who are willing to pay a fair price.

At the same time, it is feasible to combine family farming practices with the use of new technologies that improve the productive offerings and contribute to the maintenance of organic agriculture as an essence to maintain the benefits of healthy consumption and market positioning [53].

The market factor, closing the productive cycle, is vital for associativity to be sustainable and to take advantage of opportunities. For this, greater integration is also necessary, as [54] showed the relationship between the structural dimension of social capital and the intention of associativity. If efforts are dispersed within and between associations, the risk is very high. The situation of the organizations studied shows high rates of a lack of coordination and clash of interests, which transfers repetitive product offerings. It is necessary to promote alliances among them, supported by networks that bring about an approach to the systemic approach proposed by [10]. These alliances could lead to the achievement of higher levels of production and yields and more diversification of products that are articulated to market expectations; however, the family farming form of production continues to be favored, since it facilitates the use of agroecological practices.

This problem is accentuated by the absence of specific policies for the territorial level and the lack of articulation of national and sectoral policies at the local level, as opposed to the proposal of the discourse of the competent governing bodies. As a consequence, the projects assigned to the associations are atomized and do not respond to the identification and prioritization of their productive and/or organizational needs in terms of their development. In essence, these projects become very short term one-time aid distributed equally among the partners, which does not generate responsibility toward sustainability and, according to their criteria, has a medium or no impact on the socioeconomic improvement of the families. In general, non-reimbursable funds are used, which worsens their paternalistic character and influences the scarce self-determination and proactivity of the associations' members, aggravated by the fact that the aid is not coordinated and, therefore, does not respond to an integrating objective, which would multiply its effect.

Thus, the inefficiency of governance action in this context is evident, even though governance is what determines the government's ability to transform needs into policies and thus to establish patterns of interaction between strategic actors that are not biased toward interest groups (more equitable) and that allow the formulation and implementation of policies in the shortest possible time and effort (more efficient) [27].

It could be thought that decentralization is a tool to activate social participation in the design and implementation of public policies that limit government intervention, which, in general, should work. However, its mode of action must be integrated into the scope of a regional development policy, since the desired results are not achieved [55]. This issue is still valid today and is aggravated by the existing fragmentation within the country; the increase of ideas favors the exercise of governance, but efficiency and effectiveness in decision making cannot be achieved if there is no coordination and collaboration among actors [55].

In the analysis of this problem, [56] proposed an involution in relation to the development of associativity in the country, referring in particular to the implementation of projects that derive from policy action. They described the example of FARPSE, whose origin is recent (2018); this program limits its scope to a few provinces and also depends on external funding from the Agricultural Development Fund (FIFA). This evidences the existence of limitations in the implementation of national policies, given their dependence on international institutions that are alien to the concrete situation that exists in the country. 
The authors emphasized that this situation is not new; it was already present with the Poverty Reduction and Local Rural Development Project (PROLOCAL), financed by the World Bank, in addition to the high volatility of funds between national sub-programs.

Despite the above, many of the families surveyed see the association as an opportunity to sell better, work with partners and obtain government aid. In other words, for them, the association constitutes a hopeful alternative to improve their situation. Certainly, there are policy programs and projects whose scope is intended to have an impact on the dynamics of rural areas, and there is also a legal framework in place to implement them, along with mechanisms to regulate and control their operation. Ecuador, for example, as a member of the Andean Community of Nations (CAN), adheres to the Andean System of Agricultural Price Bands; the minimum support price is a base price that is implemented if farm-gate prices fall significantly. In both cases, these are selected products, delivery of subsidized inputs and organizational strengthening projects for the associations. These products are traditionally exported to other destinations. In view of this, Reference [57] indicated that these policies do not reach small producers despite the fact that the vast majority of subsistence family UPAs have scarce productive resources such as land, water, technology and capital [58]. The ministry itself recognizes this situation when it states that the absence of differentiated policies by territories ignores their heterogeneity, causing them to be exclusive, which leads to a waste of the endogenous resources of the localities [59].

The inefficiency of the impact of policies at the territorial level becomes more evident when the actors with the intention of complying with the policies established by the government but uncoordinated promote actions; these actions are carried out in a haphazard manner under the category of "Aid". Most of these aids take the form of training, which shows the lack of integration of the actors' actions in the territory; they are atomized and repetitive, causing discontent and demotivation among the members of the associations.

The lack of integration in favor of policy compliance seems to be a problem that encompasses the region; an example of this is the study carried out by [54] in relation to the implementation of the program at the municipal level of the Mexican Special Program for Food Security (PESA). In the analysis of the effects on the rural environment, they emphasized the importance of adopting policies integrated into the territory that overcome sectoral barriers in effective proposals for governance at the territorial level.

Therefore, policies should be aimed at strengthening governance at the territorial scale; the possible courses of action (short-term) discussed with the participation of the actors in the specific case study are based on the design and formulation of projects in two areas.

Each association based on the diagnosis made could formulate, with the help of the researchers, at least one project, and then, based on certain criteria with emphasis on scope and feasibility, the local government budget would be distributed.

Alliances could be developed between the associations, based on the design of an Integrated Commercialization Project, which would respond to the needs of selected market segments, such as universities, health institutions or others, generating a direct commercialization channel. This proposed solution would contribute to the sustainability of the productions of these associations, the increase of efficiency in the use of resources and the consolidation of values based on solidarity and collaboration.

In the long term, there is a need to concretize the interaction between the different levels of management and, therefore, of the actors who make decisions in this context. This implies the need to reformulate their forms of action in favor of the participation of the members of these associations in the solution of the diagnosed problems and the reformulation of policies at the local level that are articulated with their real demands.

In this regard, it is suggested to organize an ad hoc group, with the participation of private, public, associative, productive and financial institutions and academia, to function as an advisory body for decision making by the parish government. Among the functions of this group could be the formulation of policies that are concretized in long-term strategies, thus avoiding the weight of influence in decision making motivated by the interests of political power in the territories. 


\section{Conclusions}

The inadequacies with respect to the effectiveness and efficiency of policy implementation at the territorial level are evidenced in the maintenance of poverty levels in the locality, the inconsistencies present in the management of associations and the lack of coordination of actors at this level, which hinders governance and prevents approaching the operation of a subsystem that achieves synergies with the national system.

As a regularity, it is evident that the situation has not changed substantially in recent years; policies in favor of the development of associativity, particularly in rural areas, have been weak and inefficient; they are oriented toward strategic and structural changes but do not yet cause important ruptures in the paradigm of the capitalist system. The conditions of structural heterogeneity remain, which has an impact on distribution systems; there is a high level of deconcentrating of small producers who do not achieve levels of economic growth that would allow them to improve the living conditions of their families. As a result, family farming is limited in terms of access to technologies, capital and markets; efforts to incorporate new alternatives to the traditional market are scarce and have little impact, and in general, there is perfect competition, all of which leads to migration and the dependence of these families on alternative sources of income.

With respect to the functioning of the organizations, it is evident that agriculture does not generate enough income to cover expenses. Production planning is not practiced, which hinders the possibility of systematizing production and guaranteeing a constant minimum volume of supply to take advantage of market opportunities. Innovative marketing channels are not strengthened in favor of the practice of short circuits and fair trade and/or actions aimed at influencing the population to develop an awareness of responsible consumption, which would make it possible to consider the differentiation factor in favor of agroecological products that would contribute to their positioning in the market.

In addition, the most significant problem reported by the members of the associations was the "Lack of organization, union and commitment". It is presumed that this may be related to the fact that in most of the families (55\%), the member of the association is not the head of household. This may detract from the priority of fulfilling the commitments acquired within the associations. The economic differences "Intra" and "Between" the associations imply differences in the capacities to assume and fulfill their agreements. An important part of the families' expectations regarding the associations refers to particular benefits, beyond the collective efforts. This indicates that the necessary changes in relation to collaboration for the implementation of an integrated effort toward the fulfillment of a common objective are not yet part of the beliefs and values that sustain the culture of these communities. Therefore, they are not yet approaching a PES associative solution with a systemic approach, thus missing the potential to leverage social capital.

In summary, the research findings show that the policies dictated by the government, the broad constitutional-legal framework and the specialized mechanisms created for this purpose are insufficient to contribute to the strengthening of associative entrepreneurship initiatives in rural areas as an alternative to poverty at the local level.

In this sense, the exercise of governance is weak, and efforts at the territorial level are dispersed; given the insufficient integration among actors and the absence of a clear direction, the particularities of the local context are not addressed. There are no strategic interactions among decision makers at this level, and there is a lack of coordination and collaboration, which prevents policies from being fully adapted to the needs of citizens.

Therefore, people whose livelihoods depend mainly on agriculture and who are organized in family farming organizational forms live in poverty. Grouping together, they try to develop alternatives under the associative form, but the gaps in their management, their levels of dependency and the existing market failures prevent them from achieving the desired results. Given these circumstances, they are far from the possibility of achieving at least a subsystem that functions coherently within the dynamics and integration of the various forms that make up the economic system at the national level, which would contribute to increasing the effectiveness of policies. 
In summary, the role of the State is fundamental to foster the growth and development of these associations, and a reformulation of public policies is needed to promote the generation of value through the incorporation of transformation processes into economic activity. In addition, the emphasis of these actions should be aligned with governance in favor of organizational strengthening so that the small producers that make up these associations have the opportunity and sufficient motivation to find new ways to manage their production and market it. Programs and projects should favor short-channel structures, promoting alliances with institutions to facilitate secure markets, willing to pay a fair price for the benefits of agroecological production and the creation of networks that contribute to systemic competitiveness and territorial development.

As part of the actions derived from the study, once the stakeholders become aware of the need to integrate decisions in favor of improving the quality of life of the local inhabitants, it is suggested that an ad hoc group be formed, composed of representatives of private companies, associative organizations, financial organizations, academia and the community. Its main function is to act as an advisor for the formulation of policies and the implementation of strategies that contribute to the development of the territory.

Author Contributions: Conceptualization, G.G.-C. and D.P.H.-T.; methodology, G.G.-C. and A.J.V.L.; software, J.P.V.-L.; validation, G.G.-C.; formal analysis, J.P.V.-L.; investigation, G.G.-C. and D.P.H.-T.; resources, A.J.V.-L.; writing—original draft preparation, G.G.-C., D.P.H.-T. and A.J.V.L.; writing - review and editing, J.P.V.-L. All authors have read and agreed to the published version of the manuscript.

Funding: This research received no external funding.

Institutional Review Board Statement: Not applicable.

Informed Consent Statement: Informed consent was obtained from all subjects involved in the study. Certificate issued by the Research Coordination Office-Politécnica Salesiana University, Cuenca Regional Campus; dated: 23 November 2021.

Data Availability Statement: The data reported in the research is property of Grupo de Investigación para la Gestión de las Mipymes (GIGMP) of the Universidad Politécnica Salesiana del Ecuador.

Conflicts of Interest: The authors declare no conflict of interest.

\section{References}

1. CEPAL. Perspectivas de la Agricultura y del desarrollo rural en las Américas: Una mirada hacia América Latina y el Caribe 2019-2020. Available online: https://repositorio.cepal.org/bitstream/handle/11362/45111/CEPAL-FAO2019-2020_es.pdf? sequence $=1 \&$ is Allowed $=y$ (accessed on 6 February 2020).

2. Martins, C.E.; Marini, R.M. América Latina, Dependencia y Globalización, CLACSO, 2009. ProQuest Ebook Central 2018. Available online: http:/ / ebookcentral.proquest.com/lib/bibliotecaupssp/detail.action?docID=3186504 (accessed on 20 May 2019).

3. INEC. Reporte de Pobreza y Desigualdad. Boletín Técnico N02-2021-ENEMDU. 2020. Available online: https://www. ecuadorencifras.gob.ec/documentos/webinec/POBREZA/Boletin\%20tecnico\%20pobreza\%20diciembre\%202020.pdf (accessed on 15 January 2019).

4. Bernal, C.A. Metodología de la Investigación Administración, Economía, Humanidades y Ciencias Sociales, 3rd ed.; Prentice Hall: Hoboken, NJ, USA, 2011.

5. Burgos, A.L.; Bocco, G. Contribuciones a una teoría de la innovación rural. Cuad. Econ. 2020, 39, 219-247. [CrossRef]

6. Programa de las Naciones Unidas para el desarrollo PNUD. Informe Sobre Desarrollo Humano 2014 Sostener el Progreso Humano: Reducir Vulnerabilidades y Construir Resiliencia; PNUD: New York, NY, USA, 2014.

7. Alvarado, N. Debate Internacional Sobre Pobreza. Rev. Cienc. Soc. 2016, 22, 104-121. [CrossRef]

8. FAO. Marco Estratégico de Mediano plazo de Cooperación de la FAO en Agricultura Familiar en América Latina y el Caribe. Available online: https:/ /www.fao.org/3/as169s/as169s.pdf (accessed on 10 December 2018).

9. Centro de Estudios para el Desarrollo Rural Sustentable y la Soberanía Alimentaria (CEDRSS). Reporte del CEDRSSAR Elementos Para la Definición de la Agricultura Familiar. 2014. Available online: http:/ / www.cedrssa.gob.mx/files/b/13/90Agricultura_ familiar.pdf (accessed on 20 January 2019).

10. Martínez Valle, L. La Agricultura Familiar en El Ecuador; Serie Documentos de Trabajo N¹47. Grupo de Trabajo: Desarrollo con Cohesión Territorial. Programa Cohesión Territorial para el desarrollo; RIMISP: Santiago, Chile, 2013.

11. Ramos, A. Definición de "agricultura familiar" como categoría socioeconómica. Redes Rev. Do Desenvol. Soc. 2016, 21, 10-28. [CrossRef] 
12. Carrión, D.; Herrera, S. Ecuador Rural del Siglo XXI. Soberanía Alimentaria, Inversión Pública y Politica Agraria; Ediciones la Tierra: Quito, Ecuador, 2012.

13. Heifer. Agricultura Familiar Agroecológica Campesina en el Ecuador. 2010. Available online: http://www.heifer-ecuador.org/ wp- (accessed on 15 September 2018).

14. González, J.; Ordoñez, J. Estructura económica nacional: Breve análisis del sector agrícola ecuatoriano. Yachana Rev. Cient. 2015, 4, 93-100.

15. Viteri, M.P.; Tapia, M.C. Economía ecuatoriana: De la producción agrícola al servicio. Rev. Espac. 2018, 39. Available online: https:/ / www.revistaespacios.com/a18v39n32/a18v39n32p30.pdf (accessed on 14 December 2018).

16. Ministerio de Agricultura y Ganadería. La Política Agropecuaria Ecuatoriana Hacia el Desarrollo Territorial Rural Sostenible 2015-2025. 2016. Available online: http:/ / extwprlegs1.fao.org/docs/pdf/ecu183434.pdf (accessed on 4 December 2019).

17. Ministerio de Agricultura y Ganadería. SIPA. 2019. Available online: http://sipa.agricultura.gob.ec/index.php/indicadoragroeconomico (accessed on 3 September 2019).

18. Jubeto, Y.; Guridi, L.; Fernández-Villa, M. Diálogos Sobre Economía Social y Solidaria en Ecuador: Encuentros y Desencuentros con las Propuestas Para Otra Economía. Universidad del país Vasco y Hegoa. Available online: https:/ / publicaciones.hegoa.ehu. eus/uploads/pdfs/256/Dialogos_sobre_ESS_en_Ecuador.pdf?1488539810 (accessed on 10 May 2019).

19. Razzeto, L. Los Caminos de la Economía y Solidaridad; Ediciones Vivarium: Santiago, Chile, 1993.

20. Razeto, L. La economía solidaria: Concepto, realidad y proyecto. Socioeco.org. Sito de recursos de la Economía social y Solidaria. Pers. Soc. 1999, 14. Available online: http:/ / www.socioeco.org/bdf_fiche-document-137_es.html (accessed on 10 May 2019).

21. Coraggio, J.L. La Construcción de Una Economía Popular: Vía Para el Desarrollo Humano. 1993. Available online: https: / / coraggioeconomia.org/jlc/archivos\%20para\%20descargar/RAZETOART.pdf (accessed on 4 April 2019).

22. Coraggio, J.L. Las tres corrientes de pensamiento y acción dentro del campo de la economía social y solidaria. Estud. Urbanos Reg. 2013, 15, 11-24. [CrossRef]

23. Barbetti, P.A. La Economía Social Desde La Periferia. Contribuciones Latinoamericanas. Cuad. Urbano 2011, 10. [CrossRef]

24. Albuquerque, F. Desarrollo económico local y descentralización en América Latina. CEPAL 2004, 82, 157-171. [CrossRef]

25. Alburquerque, F. Teoría y práctica del enfoque del desarrollo local. OIDLES 2007, 1, 1-24.

26. Vázquez-Barquero, A. Small-scale industry in rural areas: The Spanish experience since the beginning of this century. In The Balance between Industry and Agriculture in Economic Development; Arrow, K.J., Ed.; Mcmillan: London, UK, 1998.

27. Prats, J.O. El concepto y el análisis de la gobernabilidad. Rev. Inst. Desarro. 2013, 14-15, 239-269.

28. Del Castillo-Alemán, G. Las políticas educativas en México desde una perspectiva de política pública: Gobernabilidad y gobernanza. Magis Rev. Int. Investig. Educ. 2012, 4, 637-652.

29. Camou, A. Los Desafíos de la Gobernabilidad; Estudio Preliminar; FLACSO, IIS, UNAM, Eds.; FLACSO: Mexico, Mexico, 2001.

30. Aguilar, L.F. Gobernanza: El Nuevo Proceso de Gobernar. Fundación Friedrich Naumann Para la Libertad: México, 2010. Available online: https:/ / repositorio.uesiglo21.edu.ar/handle/ues21/12820 (accessed on 7 July 2019).

31. Altamirano, M.; Martínez, J.F. Significado y Cauce de la Gobernabilidad en el Estudio de los Sistemas Políticos. Rev. Legis. Estud. Soc. 2012, 5, 255-269.

32. Montero, J.C. Gobernabilidad: Validez/Invalidez o moda del concepto. Rev. Mex. Cienc. Políticas Soc. 2012, 216, 9-23. [CrossRef]

33. Mayorga, F.; Córdova, E. Gobernabilidad y Gobernanza en América Latina. Working Paper NCCR Norte-Sur IP8, Ginebra. 2007. Available online: http:/ / www.institut-gouvernance.org/es/analyse/fiche-analyse-334.html (accessed on 6 January 2019).

34. Pelaez, V.A. La gobernanza, una nueva forma de hacer Gobierno. Sur Acad. 2017, 7, 13-18.

35. Chilito, E.A. Participación comunitaria, gobernanza y gobernabilidad. Experiencias de construcción de paz en el departamento del Cauca, Colombia, y su aporte al posconflicto, el caso del corregimiento de Lerma. Estud. Políticos 2018, 53, 51-72. [CrossRef]

36. Mideiros, A. Economía Solidaria: Crecer (re)distribuyendo Para Erradicar la Pobreza. Chakana Ecuador. Revista de Análisis de la Secretaria Nacional de Planificación y Desarrollo 2015. Available online: https:/ /www.planificacion.gob.ec/wp-content/ uploads/downloads/2015/08/CHAKANA8.pdf (accessed on 16 March 2019).

37. Vázquez-Barquero, A. Local development, a strategy for times of crisis. Int. J. Hum. Dev. Int. Coop. 2009, 1, 1-11.

38. Coraggio, J.L. Economía Social y Solidaria El Trabajo Antes que el Capital. Quito: Ediciones Abya-Yala, 2011. Ley orgánica de Economía Popular y Solidaria. 2011. Available online: http://www.sPSE.gob.ec/documents/20181/25522/Ley\%20Orga\%CC\% 81nica\%20de\%20Economi\%CC\%81a\%20Popular\%20y\%20Solidaria.pdf/0836bc47-bf63-4aa0-b945-b94479a84ca1 (accessed on 12 July 2019).

39. SPSE. La Economía Popular y Solidaria: Un Modelo Viable de Desarrollo Económico. Documentos de trabajo 2018. Available online: https:/ / www.seps.gob.ec/interna-npe?24502 (accessed on 16 March 2019).

40. SPSE. Rendición de Cuentas 2019. Available online: https://www.sPSE.gob.ec/documents/20181/920315/Rendici\%C3\%B3n+ de+Cuentas+2019.pdf/871a6012-6949-4a12-a904-95e52fa08569 (accessed on 20 September 2019).

41. Bertossi, R.F. Propuestas para una educación cooperativa en un contexto de economía social. Oidles 2007, 1, 7.

42. Gobierno Autónomo Descentralizado Muicipal del Cantón Cuenca. Plan de desarrollo y ordenamiento territorial del Cantón Cuenca Actualización 2015. Available online: http://www.cuenca.gob.ec/?q=system/files/PDOT_Completo_2015.pdf (accessed on 3 July 2019).

43. Hernández-Sampieri, R.; Mendoza, C.P. Metodología de la Investigación: Las Rutas Cuantitativa, Cualitativa y Mixta; McGraw-Hill Interamericana Editores, S.A. de C.V.: Ciudad de México, Mexico, 2018. 
44. Alvarez-Gayou, J.L. Cómo Hacer Investigación Cualitativa: Fudamento y Metodología; Paidos Ibérica Ediciones: Barcelona, Spain, 2003.

45. Sánchez-Vidal, A. Empoderamiento, liberación y desarrollo humano. Psychosoc. Interv. 2007, 26, 155-163. [CrossRef]

46. Montero-Muñoz, S.; Calderón-Gómez, N. Asociatividad, liderazgo inclusivo y desarrollo económico local. El Grupo de Artesanos Independientes de Mompox. Bitácora Urbano Territ. 2019, 30. [CrossRef]

47. CEPAL. Panorama Social de América Latina 1999-2000. 2000. Available online: https://www.cepal.org/es/publicaciones/1256 -panorama-social-america-latina-1999-2000 (accessed on 3 July 2019).

48. Mellor, J.W.; Sohail, J.M. The Impact of Growth in Small Commercial Farm Productivity on Rural Poverty Reduction. World Dev. 2017, 91, 1-10. [CrossRef]

49. Inter-American Institute for Cooperation on Agriculture (IICA). Situación de la Institucionalidad de Apoyo a la Innovación Comercial de la Agricultura Familiar y de los Procesos de Gestión Comercial de la Agricultura Familiar en el Perú Recuperado de. 2016. Available online: https: / tapipedia.org/node/39341 (accessed on 19 July 2019).

50. Tamago, L.; Iermanó, M.; Sarandón, S. Los Saberes y Decisiones Productivo-Tecnológicas en la Agricultura Familiar Pampeana: Un mecanismo de Resistencia al Modelo de Agricultura Industrial; Mundo Agrario, No 42; Universidad Nacional de la Plata: La Plata, Argentina, 2018; Volume 19.

51. Shenggen, F.; Brzeska, J.; Keyzer, M.; Halsema, A. From Subsistence to Profit Transforming Smallholder Farms; International Food Policy Research Institute: Washington, DC, USA, 2013.

52. Gáfaro, M.M.; Ocampo, J.A.; Monroy, S.D.; Rueda, A. Revisión de experiencias de apoyo a la agricultura familiar. Rev. Ens. Sobre Política Económica 2019, 91, 1-77. [CrossRef]

53. Díaz, M.A.; Córdoba, C.A. Estudio de la estructura del agroecosistema cafetero mediante el diagrama de ciclos causales. J. Depopul. Rural. Dev. Stud. 2019, 28, 135-160.

54. Rodríguez de Pepe, M.; Servilla-Ruano, M.A. Asociatividad empresarial y fuentes de capital social: Hacia un modelo explicativo. Innovar 2020, 30, 107-122. [CrossRef]

55. CEPAL. Políticas Públicas y Agriculturas Familiares en América Latina y el Caribe Balance, Desafíos y Perspectivas; Impreso en Naciones Unidas: Santiago, Chile, 2014.

56. Villalba-Eguiluz, U.; Arcos-Alonso, A.; Perez de Mendiguren, J.C.; Urretabizkaia, L. Social and Solidarity Economy in Ecuador: Fostering and alternative development model? Sustainability 2020, 12, 6876. [CrossRef]

57. Egas, J.J.; Shik, O.; Inurritegui, M.; Paolo de Salvo, C. Informes de Política Agropecuaria. Análisis de Políticas Agropecuarias en Ecuador; Banco Interamericano de Desarrollo: Washington, DA, USA, 2018.

58. García-Palacios, E.; Moyano, E. Gobernanza y desarrollo territorial. Las agencias de desarrollo rural en la implementación del programa mexicano. J. Depopul. Rural. Dev. Stud. 2019, 28, 185-215.

59. CEPAL. Cincuenta Años de Pensamiento en la CEPAL, Textos Seleccionados; Fondo de Cultura Económica: Santiago, Mexico, 1998. 